\title{
Hyperinsulinemic Hypoglycemia in a Patient with Costello Syndrome: An Etiology to Consider in Hypoglycemia
}

\author{
Dogus Vurallia ${ }^{a}$ Can Kosukcu $^{\mathrm{b}}$ Ekim Taskiran ${ }^{\mathrm{b}}$ \\ Pelin Ozlem Simsek-Kiper ${ }^{c}$ Gulen Eda Utine ${ }^{c}$ Koray Boduroglu ${ }^{c}$ \\ Ayfer Alikasifoglu $^{\mathrm{a}}$ Mehmet Alikasifoglu ${ }^{\mathrm{b}, \mathrm{c}}$ \\ aDivision of Pediatric Endocrinology, Department of Pediatrics, Hacettepe University Medical School, \\ Ankara, Turkey; ${ }^{b}$ Department of Medical Genetics, Hacettepe University Medical School, Ankara, Turkey; \\ 'Division of Pediatric Genetics, Department of Pediatrics, Hacettepe University Medical School, Ankara, Turkey
}

\section{Keywords}

Costello syndrome $\cdot$ Diazoxide $\cdot$ Hyperinsulinism •

Hypoglycemia $\cdot$ RASopathy

\begin{abstract}
Several endocrine disorders have been defined in patients with Costello syndrome (CS). In this report, we describe a patient with CS accompanied by a clinical picture of hyperinsulinemic hypoglycemia responsive to diazoxide treatment. A 41-day-old female patient with a birth weight of $3,600 \mathrm{~g}$ was referred for atypical facial features and swallowing dysfunction. She had a weight of $4,000 \mathrm{~g}(-0.8 \mathrm{SDS})$, a length of 50 $\mathrm{cm}(-2.4$ SDS), and a head circumference of $38 \mathrm{~cm}(0.2 \mathrm{SDS})$. The clinical findings were suggestive of a genetic syndrome, mainly a RASopathy or Beckwith-Wiedemann syndrome. Whole exome sequencing revealed a de novo heterozygous missense variant in the HRAS (NM_001130442) gene in exon 2: c.35G >C; p.(Gly12Ala), establishing the molecular diagnosis of CS. The patient developed symptomatic hypoglycemia (jitteriness and sweating) at the age of 13 months. The patient's serum glucose was $38 \mathrm{mg} / \mathrm{dL}$ with simultaneous serum insulin and C-peptide levels, $2.8 \mu \mathrm{lU} / \mathrm{mL}$ and $1.8 \mathrm{ng} / \mathrm{mL}$,
\end{abstract}

respectively. Hyperinsulinism was suspected, and an exaggerated glucose response was detected in a glucagon test. Blood glucose monitoring indicated episodes of fasting hypoglycemia and postprandial hyperglycemia. Diazoxide of $10 \mathrm{mg} / \mathrm{kg} /$ day was initiated in 3 doses for hyperinsulinemic hypoglycemia, which resolved without new episodes of postprandial hyperglycemia. The patient deceased at the age of 17 months due to cardiorespiratory failure in the course of severe pneumonia complicated with pulmonary hypertension and hypertrophic cardiomyopathy. Several genetic syndromes including CS are associated with endocrinologic manifestations including abnormal glucose homeostasis. Although the frequency and underlying mechanisms leading to hyperinsulinemic hypoglycemia are yet unknown, hypoglycemia in CS responds well to diazoxide.

(c) 2020 S. Karger AG, Basel

\section{Introduction}

Costello syndrome (CS) is a rare multiple anomaly syndrome with a prevalence of $\sim 1 / 300,000$ live births and is one of the RASopathies due to germ-line variants in karger@karger.com

(C) 2020 S. Karger AG, Basel

www.karger.com/msy

Karger! $\stackrel{\text { เ }}{*}$
Dogus Vuralli

Division of Pediatric Endocrinology, Department of Pediatrics

Hacettepe University Medical School

Sihhiye Ankara 06100 (Turkey)

dvuralli@hotmail.com 
RAS/Mitogen-Activated Protein Kinase (MAPK) pathway components and regulators [Abe et al., 2012; Rauen, 2013; Tidyman and Rauen, 2016]. CS is caused by heterozygous activating de novo germline variants in HRAS (OMIM, 190020) encoding the Harvey rat sarcoma viral oncogene homologue (HRAS), which is one of the most commonly studied RAS proteins. CS affects almost all organ systems with a wide phenotypic spectrum and is associated with characteristics such as prenatal overgrowth, poor postnatal growth, global developmental delay, coarse facial appearance, loose skin of hands and feet with characteristic hand position, joint laxity, deep palmar and plantar creases, and perinasal papillomas [Gripp and Lin, 2012]. Additional features include severe feeding difficulty, cardiac abnormalities (congenital heart defects, arrhythmias, and cardiomyopathy), and a predisposition to various types of cancer, with embryonal rhabdomyosarcoma being the most common [Gripp et al., 2002; Hennekam, 2003]. Several endocrine disorders, including growth hormone deficiency, adrenal failure, glucose intolerance, parathyroid adenoma, hyperprolactinemia, and hypoglycemia have been defined in patients with CS so far [Yetkin et al., 1998; Szalai et al., 1999; Cakir et al., 2004]. In the present report, we describe a CS patient with a clinical picture of hyperinsulinemic hypoglycemia who was responsive to diazoxide treatment.

\section{Clinical Report}

The patient was the second child of a nonconsanguineous healthy couple (maternal age 26, paternal age 35) who was born by vaginal delivery at 36 weeks of gestation (Apgar scores of 6 and 8 at 1 and $5 \mathrm{~min}$, respectively) with a birth weight of $3,600 \mathrm{~g}$ (2.1 SDS). The pregnancy was complicated by polyhydramnios requiring repetitive (4 times) amniodrainage. Prenatal karyotype analysis was $46, \mathrm{XX}$. There was no history of diabetes mellitus in the family, and a $50 \mathrm{~g}$ oral glucose tolerance test was normal. At birth, the patient had respiratory distress and hypotonia requiring neonatal intensive care unit admission. She had episodes of hypoglycemia which responded to increased glucose infusion rates. The girl was discharged on postnatal day 27 with swallowing dysfunction requiring nasogastric tube feeding. She was first referred to our center when she was 41 days old for atypical facial features and swallowing dysfunction. She had a body weight of $4,000 \mathrm{~g}$ (-0.8 SDS), a body length of $50 \mathrm{~cm}(-2.4$ SDS), and a head circumference of $38 \mathrm{~cm}$ (0.2 SDS). Relative macrocephaly, coarse facial appearance, high forehead, epicanthic folds, depressed nasal root, bulbous nose, macroglossia, thick lips, and short neck were noticed. The

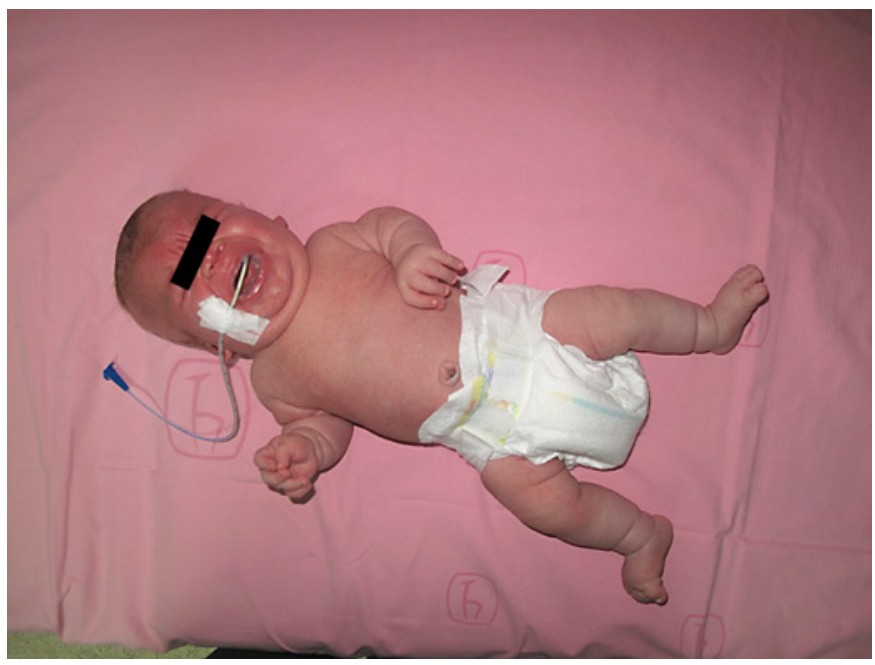

Fig. 1. Clinical photo of the patient.

skin of her hands was thick and she had deep palmar creases. Upslanted palpebral fissures, low set ears, glabellar cutaneous hemangioma, and a posterior ear lobe crease were also noted (Fig. 1).

The facial features of the patient were suggestive of genetic syndromes including RASopathies, Beckwith-Wiedemann syndrome (BWS), or lysosomal storage disorders. The patient had global developmental delay (head control at 9 months, no babbling at 10 months) and required nasogastric tube feeding since birth. She had organoaxial malrotation and gastroesophageal reflux which required Nissen fundoplication and gastrostomy procedures when she was 7 months old. While echocardiography revealed pulmonary valve stenosis and biventricular hypertrophy, Holter rhythm monitorization detected multifocal atrial tachycardia, and antiarrhythmic treatment was initiated. Cranial magnetic resonance imaging displayed a diffuse thin corpus callosum. She had increased levels of serum alpha-fetoprotein (AFP) levels (28 $\mathrm{ng} / \mathrm{mL}$; normal range $0-9 \mathrm{ng} / \mathrm{mL}$ ). No solid diagnosis could be established solely based on clinical grounds; therefore, whole exome sequencing (WES) was performed which revealed a previously reported HRAS variant, establishing the molecular diagnosis of CS.

The patient developed symptomatic hypoglycemia (jitteriness and sweating) and was evaluated at the endocrinology department at the age of 13 months. Her serum glucose level was $38 \mathrm{mg} / \mathrm{dL}$, and the concurrently measured insulin level was as high as $2.8 \mu \mathrm{IU} / \mathrm{mL}$ and C-peptide level was $1.8 \mathrm{ng} / \mathrm{mL}$. The serum cortisol response was appropriate, serum growth hormone $(\mathrm{GH})$ level at hypo- 
glycemia was a little bit below the normal level of $10 \mathrm{ng} /$ mL. Serum ammonia, lactate, pyruvate levels and serum amino acids, carnitine, and acylcarnitines levels were all normal (Table 1). Hyperinsulinism was suspected because the levels of insulin and C-peptide were elevated when measured while the patient was hypoglycemic. An exaggerated glucose response was also observed in the glucagon test, supporting the diagnosis of hyperinsulinism. Blood glucose monitoring indicated episodes of fasting hypoglycemia and postprandial hyperglycemia. Diazoxide of $10 \mathrm{mg} / \mathrm{kg} /$ day was initiated in 3 doses for hyperinsulinemic hypoglycemia, which was resolved with no new episodes of postprandial hyperglycemia occurring.

Since the patient had corpus callosum hypoplasia, the anterior pituitary hormones were evaluated as well (Table 2). Thyroid function tests, cortisol, and prolactin levels were all normal. Both IGF-1 and IGFBP-3 levels were below -3 SDS. Growth hormone level at hypoglycemia was $8.72 \mathrm{ng} / \mathrm{mL}$, and peak GH level at glucagon stimulation test was $9.07 \mathrm{ng} / \mathrm{mL}$. Peak GH levels of the patient were considered normal for this age. Total GH deficiency (GHD) was not considered, and follow-up was planned to reveal the growth velocity in terms of possible partial mild GHD. In terms of other possible hormonal disorders that may accompany CS, serum calcium, phosphorous, alkaline phosphatase, and parathormone levels were checked and were all within normal ranges. The patient deceased at the age of 17 months because of cardiorespiratory failure during a severe pneumonia probably complicated with pulmonary hypertension and hypertrophic cardiomyopathy.

\section{Materials and Methods}

After informed consent was taken from the family, a genomic DNA sample from peripheral whole blood using the standard procedure was extracted. WES was performed as described previously [Taskiran et al., 2017]. Identified variants of presumed pathogenic relevance were validated on the original DNA sample using conventional Sanger sequencing on an automated capillary sequence (Applied Biosystems 3500xL Genetic Analyzer).

\section{Results}

A de novo heterozygous, previously reported missense variant of HRAS (NM_001130442) in exon 2: c.35G>C; p.(Gly12Ala) was identified after removal of variants with high allele frequency ( $>1 \%$ in the ExAC data). Genetic counseling was provided to the family accordingly.

Hyperinsulinemic Hypoglycemia in

Costello Syndrome
Table 1. Critical blood evaluations during hypoglycemia

Glucose: $38 \mathrm{mg} / \mathrm{dL}$ (normal range: $70-100 \mathrm{mg} / \mathrm{dL}$ )

Insulin: $2.8 \mu \mathrm{IU} / \mathrm{mL}$ (normal range: $1.9-23 \mu \mathrm{IU} / \mathrm{mL}$ )

C-peptide: $1.8 \mathrm{ng} / \mathrm{mL}$ (normal range: $0.9-7.1 \mathrm{ng} / \mathrm{mL}$ )

ACTH: $26.7 \mathrm{pg} / \mathrm{mL}$ (normal range: $0-46 \mathrm{pg} / \mathrm{mL}$ )

Cortisol: $26 \mu \mathrm{g} / \mathrm{dL}$ (normal range: $6.7-22.6 \mu \mathrm{g} / \mathrm{dL}$ )

Growth hormone: $8.72 \mathrm{ng} / \mathrm{mL}$ (normal range: $>10 \mathrm{ng} / \mathrm{mL}$ )

Lactate: $13.69 \mathrm{mg} / \mathrm{dL}$ (normal range: $4.5-19.8 \mathrm{mg} / \mathrm{dL}$ )

Ammonia: $123 \mu \mathrm{g} / \mathrm{dL}$ (normal range: $20-120 \mu \mathrm{g} / \mathrm{dL}$ )

Pyruvate: $1.62 \mathrm{mg} / \mathrm{dL}$ (normal range: $0.3-0.9 \mathrm{mg} / \mathrm{dL}$ )

Urine ketone: negative

Tandem mass spectrometry: normal

Plasma and urine amino acid profiles: normal

Urine organic acid analysis: normal

Glucagon test: Glu (0 min): $44 \mathrm{mg} / \mathrm{dL}$ Glu (15 min): $126 \mathrm{mg} / \mathrm{dL}$

Glu (30 min): $156 \mathrm{mg} / \mathrm{dL}$

Table 2. Evaluation of anterior pituitary hormones

Free T4: $9.10 \mathrm{pmol} / \mathrm{L}$ (normal range: 7.86-14.41 pmol/L)

TSH: $1.607 \mu \mathrm{IU} / \mathrm{L}$ (normal range:0.38-5.33 $\mu \mathrm{IU} / \mathrm{L}$ )

ACTH: $26.7 \mathrm{pg} / \mathrm{mL}$ (normal range: $0-46 \mathrm{pg} / \mathrm{mL}$ )

Cortisol: $26 \mu \mathrm{g} / \mathrm{dL}$ (normal range: $6.7-22.6 \mu \mathrm{g} / \mathrm{dL}$ )

PRL: $16.36 \mathrm{ng} / \mathrm{mL}$ (normal range:5.18-26.53 ng/mL)

IGF-1: $4.66 \mathrm{ng} / \mathrm{mL}(<-3 \mathrm{SDS})$

IGFBP-3: $1,082.93 \mathrm{ng} / \mathrm{mL}(<-3$ SDS $)$

Peak GH level at glucagon stimulation test: $9.07 \mathrm{ng} / \mathrm{mL}$

\section{Discussion}

Costello syndrome is a multisystem disease with a broad phenotypic spectrum ranging from a milder phenotype to severe forms that lead to early lethal complications. While older children with CS can be diagnosed more reliably, it can be challenging to diagnose patients at younger ages based solely on clinical findings. The present patient had dysmorphic facial features, loose and soft skin, and deep palmar creases suggestive of CS; nevertheless, some other differentials were considered as well. In infants and young children, BWS, cardio-facio-cutaneous syndrome, Noonan syndrome, SimpsonGolabi-Behmel syndrome, Williams syndrome, and lysosomal storage disorders may be considered in the differential diagnosis of CS. The presence of various organ malformations and the absence of severe feeding difficulty and growth failure in these syndromes usually allow them to be differentiated from CS. Other clinical findings suggesting CS in the present patient's history and physical examination included polyhydramniosis, preterm delivery, macrosomic birth, relative macro- 
Table 3. The clinical findings in individuals with Costello syndrome ${ }^{\mathrm{a}}$ and in the present case

\begin{tabular}{|c|c|c|}
\hline $\begin{array}{l}\text { Organ system } \\
\text { affected }\end{array}$ & Specific findings suggestive of Costello syndrome & Specific findings in the current patient \\
\hline $\begin{array}{l}\text { Prenatal and } \\
\text { perinatal history }\end{array}$ & $\begin{array}{l}\text { On prenatal ultrasound: increased nuchal thickness, polyhydramnios, } \\
\text { characteristic ulnar deviation of the wrists, short humeri and femurs } \\
\text { Fetal tachycardia } \\
\text { Preterm delivery } \\
\text { Macrocephaly }\end{array}$ & $\begin{array}{l}\text { Polyhydramnios } \\
\text { Preterm delivery } \\
\text { Prenatal overgrowth } \\
\text { Relative macrocephaly }\end{array}$ \\
\hline $\begin{array}{l}\text { Craniofacial } \\
\text { appearance }\end{array}$ & $\begin{array}{l}\text { Coarse facial features, full cheeks, full lips, wide mouth } \\
\text { Prominent epicanthal folds } \\
\text { Dolichocilia (long eye lashes) } \\
\text { Wide nasal bridge, short full nose } \\
\text { Fleshy ear lobes } \\
\text { Curly or sparse fine hair } \\
\text { Deep, hoarse voice }\end{array}$ & $\begin{array}{l}\text { Coarse facial features, full cheeks, full } \\
\text { lips, wide mouth } \\
\text { Prominent epicanthal folds } \\
\text { Wide nasal bridge, short full nose } \\
\text { Fleshy ear lobes } \\
\text { Sparse fine hair } \\
\text { Deep, hoarse voice }\end{array}$ \\
\hline Skin & $\begin{array}{l}\text { Loose, soft skin } \\
\text { Palmoplantar keratoderma } \\
\text { Deep palmar and plantar creases } \\
\text { Papillomas } \\
\text { Acanthosis nigricans } \\
\text { Diffuse hyperpigmentation }\end{array}$ & $\begin{array}{l}\text { Loose, soft skin } \\
\text { Deep palmar and plantar creases }\end{array}$ \\
\hline $\begin{array}{l}\text { Musculoskeletal } \\
\text { system }\end{array}$ & $\begin{array}{l}\text { Distinctive hand position with ulnar deviation of the wrists } \\
\text { Vertical talus } \\
\text { Hip dysplasia } \\
\text { Tight hell cords } \\
\text { Shoulder and elbow contractures } \\
\text { Scoliosis } \\
\text { Osteopenia } \\
\text { Weakness }\end{array}$ & $\begin{array}{l}\text { Shoulder and elbow contractures } \\
\text { Weakness }\end{array}$ \\
\hline $\begin{array}{l}\text { Neurological } \\
\text { system }\end{array}$ & $\begin{array}{l}\text { Absolute or relative macrocephaly } \\
\text { Ventricular dilatation } \\
\text { Chiari } 1 \text { malformation } \\
\text { Syringomyelia } \\
\text { Tethered cord } \\
\text { Seizures }\end{array}$ & Relative macrocephaly \\
\hline
\end{tabular}


Table 3 (continued)

\begin{tabular}{|c|c|c|}
\hline $\begin{array}{l}\text { Organ system } \\
\text { affected }\end{array}$ & Specific findings suggestive of Costello syndrome & Specific findings in the current patient \\
\hline $\begin{array}{l}\text { Neurocognitive/ } \\
\text { psychological } \\
\text { functions }\end{array}$ & $\begin{array}{l}\text { Intellectual disability } \\
\text { Speech and language impairment } \\
\text { Delayed or deficient fine- and gross-motor skills } \\
\text { Impaired adaptive functioning }\end{array}$ & $\begin{array}{l}\text { Developmental delay } \\
\text { Intellectual disability } \\
\text { Speech impairment } \\
\text { Delayed or deficient fine- and } \\
\text { gross-motor skills } \\
\text { Impaired adaptive functioning }\end{array}$ \\
\hline Oncological & $\begin{array}{l}\text { Benign tumors } \\
\text { Embryonal rhabdomyosarcoma } \\
\text { Bladder carcinoma } \\
\text { Neuroblastoma }\end{array}$ & \\
\hline Gastroenterological & $\begin{array}{l}\text { Feeding and swallowing difficulties } \\
\text { Pyloric stenosis } \\
\text { Gastroesophageal reflux } \\
\text { Constipation }\end{array}$ & $\begin{array}{l}\text { Feeding and swallowing difficulties } \\
\text { Gastroesophageal reflux }\end{array}$ \\
\hline Endocrinological & $\begin{array}{l}\text { Short stature } \\
\text { Growth hormone deficiency } \\
\text { Hypoglycemia } \\
\text { Delayed or precocious puberty }\end{array}$ & $\begin{array}{l}\text { Short stature } \\
\text { Hypoglycemia (hyperinsulinemic } \\
\text { hypoglycemia) }\end{array}$ \\
\hline Respiratory & $\begin{array}{l}\text { Structural upper and lower airway anomalies } \\
\text { Frequent infections } \\
\text { Central and obstructive apnea } \\
\text { Cardiopulmonary disease }\end{array}$ & $\begin{array}{l}\text { Structural upper and lower airway } \\
\text { anomalies (respiratory distress) } \\
\text { Frequent infections }\end{array}$ \\
\hline Genitourinary & $\begin{array}{l}\text { Cryptorchidism or labial anomalies } \\
\text { Kidney malformation } \\
\text { Vesicoureteral reflux } \\
\text { Inguinal hernia } \\
\text { Transitional cell carcinoma of the bladder }\end{array}$ & \\
\hline Dental & $\begin{array}{l}\text { Delayed tooth eruption } \\
\text { Malocclusion } \\
\text { Cross bite }\end{array}$ & Delayed tooth eruption \\
\hline
\end{tabular}

a van Eeghen et al. [1999]; Lin et al. [2002, 2009]; Gripp [2005]; White et al. [2005]; Quezada and Gripp [2007]; Lin et al. [2009]; Gripp et al. [2019]

cephaly, severe postnatal feeding and swallowing difficulties, respiratory distress in the neonatal period, global developmental delay, and typical cardiac anomalies such as valvular pulmonary stenosis, hypertrophic cardiomyopathy and multifocal atrial tachycardia, of which the latter 2 may lead to death in the first 2 years of life. The present patient was lost because of pulmonary hy- pertension and cardiorespiratory failure developed as complications during severe pneumonia, and the underlying hypertrophic cardiomyopathy might have contributed to the patient's mortality. The clinical findings of the patient and other CS patients are shown in Table 3.

An important endocrinological finding observed in the present patient was the rarely seen hyperinsulinemic 
hypoglycemia. Hyperinsulinemic hypoglycemia has previously been described in some of the pre- and postnatal overgrowth syndromes which are also considered in the differential diagnosis of CS including BWS, Simpson-Golabi-Behmel syndrome, and Sotos syndrome. The most common overgrowth syndrome associated with hyperinsulinemic hypoglycemia is BWS, a somatic overgrowth and cancer predisposition syndrome with a complex genetic basis. While the association between BWS [Munns and atch, 2001; Hussain et al., 2005] and hyperinsulinemic hypoglycemia is well documented, the underlying molecular mechanisms leading to hyperinsulinemic hypoglycemia in most of the other genetic conditions, including trisomy 13 [Tamame et al., 2004], congenital disorders of glycosylation (especially CDG Ia and Ib) [Böhles et al., 2001; de Lonlay et al., 2001], Sotos syndrome, Timothy syndrome, and Kabuki syndrome, are still unclear.

The literature contains various case reports covering the endocrinological problems that accompany CS. Nevertheless, very few cases of CS with hyperinsulinemic hypoglycemia have been reported since its first association in 2005 [Alexander et al., 2005]. Neonatal hypoglycemia is also more specific for CS than for other RASopathies. The ratio of neonates and infants with CS exhibiting hypoglycemia is reported to be $44 \%$ [Gripp and Lin, 2012; Myers et al., 2014]. The glucose metabolism disorders observed in CS may take the form of hypoglycemia or postprandial hyperglycemia, although these 2 conditions may also occur concurrently, as was observed in the present case. To date, the underlying reason for these glucose metabolism disorders observed in CS has yet to be elucidated. While there have been studies claiming an association between hypoglycemia and GHD or cortisol deficiency, others claim that hyperinsulinism causes hypoglycemia in a manner similar to what was observed in the present case [Yetkin et al., 1998; Legault et al., 2001; Delrue et al., 2002; Stein et al., 2004; Alexander et al., 2005]. In addition to the hypoglycemia observed during fasting, postprandial hyperglycemia was, similar to the present case, also defined in cases with CS. Di Rocco et al. [1993] suggested that the postprandial hyperglycemia observed in these cases may be a result of insulin resistance[Di Rocco et al., 1993]. Szalai et al. [1999] reported a case with decreased glucose tolerance accompanied by acanthosis nigricans. The present patient exhibited biochemical findings typical for hyperinsulinemic hypoglycemia, and there was also a measurable serum insulin level in the presence of nonketotic hypoglycemia. Growth hormone and corti- sol levels were appropriate in response to hypoglycemia. The serum levels of ammonia, lactate, and pyruvate were all normal. The carnitine/acylcarnitine profiles, urine organic acids, urinary and plasma amino acid profiles were normal as well. As observed in other CS patients with hyperinsulinemic hypoglycemia, the present patient also responded well to diazoxide treatment, which led to the resolvement of the hypoglycemia. Following diazoxide treatment, no reoccurrence was noted of the postprandial hyperglycemias observed prior to treatment.

An evaluation of the patient with regard to other endocrinological problems commonly reported with CS revealed normal thyroid function, normal prolactin levels, and no goiter. Furthermore, when the patient was evaluated with regard to parathyroid adenomas that were reported in similar cases, calcium, phosphorous, alkaline phosphatase, and parathormone values were all found to be normal. The patient exhibited no cortisol deficiency or total GHD. Concerning the peak GH response observed in the GH stimulation tests, there are no defined normal values for the patient's age group. While some consider $7 \mathrm{ng} / \mathrm{mL}$ and above as normal for this age group, others consider $10 \mathrm{ng} / \mathrm{mL}$ to be normal, independent of age [Ranke, 2011; Wagner et al., 2014; Guzzetti et al., 2016]. Although the present patient was identified as having low IGF-1 and IGFBP3 values, which is in agreement with a clinical picture of GHD, we did not consider starting GH treatment on the grounds that the hypoglycemia resolved completely with diazoxide treatment and that the peak GH response of the patient was very close to normal values. With respect to GHD, we planned to monitor the growth velocity of the patient. While there are publications in the literature reporting that GH treatment in patients supposed to have total GHD resolved their hypoglycemia, other publications report that $\mathrm{GH}$ treatment in cases presumed to have partial GHD only resulted in a limited response [Okamoto et al., 1994; Yetkin et al., 1998; Legault et al., 2001; Gregersen and Viljoen, 2004; Stein et al., 2004].

Gene-targeted testing using either a single-gene testing for HRAS or a multi-gene panel for RASopathies is recommended in the molecular diagnosis of CS, especially in patients with distinctive clinical findings. However, this may not always be the case as it was in the present patient. Since CS has a broad spectrum of clinical findings and some other genetic syndromes with overlapping features are considered in the differential diagnosis, comprehensive genomic testing (such as exome sequencing and genome sequencing) may be required. 
Table 4. Genotype-phenotype correlations in Costello syndrome [Lo et al., 2008; Gripp et al., 2019]

\begin{tabular}{|c|c|}
\hline HRAS mutation & Clinical phenotype \\
\hline p.Gly12Ser & Classic features of CS \\
\hline p.Gly12Cys, p.Gly12 Asp, p.Gly12Glu & $\begin{array}{l}\text { Severe neonatal phenotype } \\
\text { Severe cardiomyopathy } \\
\text { Pleural and pericardial effusion } \\
\text { Lung abnormalities }\end{array}$ \\
\hline p.Gly12Ala & $\begin{array}{l}\text { Severe neonatal phenotype } \\
\text { Higher rate of malignancy }\end{array}$ \\
\hline p.Gly12Val & $\begin{array}{l}\text { Severe cardiomyopathy } \\
\text { Tachycardia } \\
\text { Respiratory distress } \\
\text { Early death }\end{array}$ \\
\hline p.Gly13Cys & $\begin{array}{l}\text { Milder phenotype } \\
\text { Lower risk for malignant tumors or papillomata } \\
\text { Taller stature } \\
\text { Absence of ulnar wrist deviation }\end{array}$ \\
\hline p.Thr58Ile, p.Lys117Arg, p.Ala146Val, p.Ala146Pro & $\begin{array}{l}\text { Milder phenotype } \\
\text { Facial features are less coarse }\end{array}$ \\
\hline p.Gly60Asp & $\begin{array}{l}\text { Milder phenotype } \\
\text { Reported with maternal transmission }\end{array}$ \\
\hline p.Gly60Val & $\begin{array}{l}\text { Only one case reported } \\
\text { Died in infancy }\end{array}$ \\
\hline p.Glu63Lys & $\begin{array}{l}\text { Classic features of CS } \\
\text { Congenital myopathy }\end{array}$ \\
\hline p.Glu63_Asp69dup & $\begin{array}{l}\text { Milder phenotype } \\
\text { Milder intellectual disability } \\
\text { Fewer feeding problems } \\
\text { Lower tumor risk }\end{array}$ \\
\hline p.Ala146Thr & $\begin{array}{l}\text { Milder phenotype } \\
\text { Minor skin and joint involvement } \\
\text { Milder growth restriction } \\
\text { Microcephaly } \\
\text { Sparse, thin hair }\end{array}$ \\
\hline p.Gly37dup & $\begin{array}{l}\text { Very sparse hair } \\
\text { Facial features are less coarse }\end{array}$ \\
\hline p.Gly13Asp & $\begin{array}{l}\text { Milder phenotype } \\
\text { Fewer malignancy }\end{array}$ \\
\hline
\end{tabular}

The present patient exhibited swallowing dysfunction, facial dysmorphism, global developmental delay, and some minor anomalies, findings shared by several other genetic conditions, including Noonan syndrome, cardio-facio-cutaneous syndrome, BWS, and lysosomal storage disorders. Therefore, a solid diagnosis based solely on clinical grounds could not be established and WES was performed for the exact diagnosis.

Hyperinsulinemic Hypoglycemia in Costello Syndrome
CS typically arises de novo from the paternal germline as a result of heterozygous activating variants in HRAS located at 11p15.5 [Sol-Church et al., 2006; Giannoulatou et al., 2013]. Advanced paternal age is present in most of the cases with HRAS variants [Aoki et al., 2005; Estep et al., 2006; Sol-Church et al., 2006; Giannoulatou et al., 2013]. The present case also had advanced paternal age. Sometimes somatic mosaicism can 
be observed in individuals with a milder phenotype involving a limited number of organ systems [Gripp et al., 2006b, 2017; Sol-Church et al., 2009]. Despite the limited available data due to the rarity of CS, some genotype-phenotype correlations have previously been reported. More than $95 \%$ of HRAS variants that cause CS involve the amino acid glycine at the 12th or 13th position in HRAS [Sol-Church and Gripp, 2009]. About 80\% of variants cause a p.Gly12Ser missense change, resulting in the classical phenotype. In the present case, WES revealed a previously reported pathogenic missense variant (p.Gly12Ala) in HRAS which involves the alteration of a conserved nucleotide [Aoki et al., 2005; Niihori et al., 2011; Robbins et al., 2016]. This variant not only represents the second most common mutation reported in CS [Aoki et al., 2005; Gripp et al., 2006a; Kerr et al., 2006] but also has been associated with a higher risk of malignancy with a more severe phenotype. With this clinical report we also have shown that hyperinsulinism may be another clinical feature of CS. Other HRAS variants known to be related to hyperinsulinism in the literature are p.Gly12Glu, and p.Gln22Lys. Rare variants in CS may also be associated with hyperinsulinemic hypoglycemia compared to the commonly encountered p.Gly12Ser variant. The other already known genotypephenotype correlations in CS are given in Table 4.

Dickson et al. [2004] identified for the first time a case of CS with pancreatic hyperplasia [Dickson et al., 2004]. A year later, Alexander et al. [2005] reported 2 cases in which hyperinsulinemic hypoglycemia was the underlying reason for the hypoglycemia seen during fasting with CS. Severe neonatal hypoglycemia accompanying congenital hyperinsulinism was identified in an individual with an HRAS p.Gly12Glu mutation, and the autopsy of this case revealed hypertrophy and hyperplasia in the Langerhans cells [Kerr et al., 2006]. In 2015, Sheffield et al. also reported hyperinsulinemic hypoglycemia in a rare case with a p.Gln22Lys mutation in HRAS [Sheffield et al., 2015]. This patient eventually developed and died of medical treatment-resistant pulmonary hypertension and hypertrophic cardiomyopathy. Postmortem examinations identified a pancreatic nodule that was similar to the focal lesions seen in congenital hyperinsulinism. Studies of this nodule, however, revealed no underlying molecular changes (no mutation in $K C N J 11$ or $A B C C 8$ which are located at 11 p15.1 close to HRAS at $11 \mathrm{p} 15.5)$ that might have led to hyperinsulinism. In addition, it has been shown that epigenetic alterations in the IGF2 and $\mathrm{H} 19$ loci that are seen in BWS are not present but that there is a loss of CDKN1C ex- pression in the nodule; the reason for this could not be explained. In 2016, Gripp et al. performed studies on the lesion of this case who has both CS and the pancreatic nodule, and demonstrated that, similar to the paternal uniparental disomy (pUPD) of $11 \mathrm{p} 15.5$ seen in cases with BWS, the patient in question had UPD [Gripp et al., 2016]. According to Gripp et al. [2016], demonstrating the loss of heterozygosity in the pancreatic lesion of a case with CS not only explains the neonatal hypoglycemia observed in these cases but also suggests that a combination of heterozygosity loss and pUPD may be the mechanism that leads to disorders of cell growth and tumor formation. This mechanism would explain both hyperinsulinism and the tumor and papillomata formation observed in CS. In isolated sporadic malignancies, somatic variants in KRAS and HRAS have been reported at varying frequencies. The risk of malignancy in CS is considerably higher when compared to other RASopathies that develop as a result of KRAS variants, such as Noonan syndrome. This difference might be related to the different effect and function of HRAS compared to KRAS. That said, it may also be attributable to the colocalization of IGF2 in this region and the contribution of the combined effect of pUPD on both the HRAS and IGF2 genes to its oncogenic potential within 11p15.5. Kerr et al. [2003] also showed the loss of heterozygosity at 11 p15.5 in rhabdomyosarcoma and suggested that loss of the wild-type allele could be the second hit in tumor development in patients with CS [Kerr et al., 2003]. This theory is furthermore supported by several authors who showed the monoallelic expression and the loss of the wild-type allele in CS-associated tumors [Aoki et al., 2005; Estep et al., 2006].

In conclusion, several developmental genetic syndromes including CS are associated with endocrinologic manifestations. Hyperinsulinemic hypoglycemia, one of the endocrinologic manifestations of abnormal glucose homeostasis, should be kept in mind in CS patients. Although the frequency and the underlying mechanisms leading to hyperinsulinemic hypoglycemia in CS is yet unknown, hypoglycemia responds well to diazoxide treatment.

\section{Statement of Ethics}

Informed consent was obtained from the parents, and investigations were conducted in line with the principles detailed by the Declaration of Helsinki. 


\section{Conflict of Interest Statement}

The authors have no conflicts of interest to declare.

\section{Funding Sources}

No funding was received.

\section{Authors Contributions}

All authors read and approved the manuscript.

D.V. participated in the design of the study, performed clinical investigations, and wrote the manuscript. C.K. and E.T. performed the molecular investigations. P.O.S.-K. and A.A. participated in the design of the study, contributed to performing clinical investigations and writing the manuscript. G.E.U. participated in the design of the study and contributed to the clinical investigations. K.B. and M.A. coordinated the molecular investigations and the coordination of the study.

\section{References}

Abe Y, Aoki Y, Kuriyama S, Kawame H, Okamoto N, Kurosawa K, et al. Prevalence and clinical features of Costello syndrome and cardiofacio-cutaneous syndrome in Japan: findings from a nationwide epidemiological survey. Am J Med Genet A. 2012;158A(5):1083-94

Alexander S, Ramadan D, Alkhayyat H, AlSharkawi I, Backer KC, El-Sabban F, et al. Costello syndrome and hyperinsulinemic hypoglycemia. Am J Med Genet A. 2005;139(3): 227-30.

Aoki Y, Niihori T, Kawame H, Kurosawa K, Ohashi H, Tanaka Y, et al. Germline mutations in HRAS proto-oncogene cause Costello syndrome. Nat Genet. 2005;37(10):1038-40.

Böhles H, Sewell AA, Gebhardt B, Reinecke-Lüthge A, Klöppel G, Marquardt T. Hyperinsulinaemic hypoglycaemia--leading symptom in a patient with congenital disorder of glycosylation Ia (phosphomannomutase deficiency). J Inherit Metab Dis. 2001;24(8):858-62.

Cakir M, Arici C, Tacoy S, Karayalcin U.. A case of Costello with parathyroid adenoma and hyperprolactinemia. Am J Med Genet A. 2004;124A(2):196-9.

de Lonlay P, Seta N, Barrot S, Chabrol B, Drouin $\mathrm{V}$, Gabriel BM, et al. A broad spectrum of clinical presentations in congenital disorders of glycosylation I: a series of 26 cases. J Med Genet. 2001;38(1):14-9.

Delrue MA, Arveiler B, Lacombe D. Costello syndrome: clinical aspects and tumor risk. Arch Pediatr. 2002;9(10):1059-63.

Di Rocco M, Gatti R, Gandullia P, Barabino A, Picco P, Borrone C.. Report on two patients with Costello syndrome and sialuria. Am J Med Genet. 1993;47(7):1135-40.

Dickson PI, Briones NY, Baylen BG, Jonas AJ, French SW, Lin HJ.. Costello syndrome with pancreatic islet cell hyperplasia. Am J Med Genet A. 2004;130A(4):402-5.

Estep AL, Tidyman WE, Teitell MA, Cotter PD, Rauen KA.. HRAS mutations in Costello syndrome: detection of constitutional activating mutations in codon 12 and 13 and loss of wild-type allele in malignancy. Am J Med Genet A. 2006;140(1):8-16.
Giannoulatou E, McVean G, Taylor IB, McGowan SJ, Maher GJ, Iqbal Z, et al. Contributions of intrinsic mutation rate and selfish selection to levels of de novo HRAS mutations in the paternal germline. Proc Natl Acad Sci USA. 2013;110(50):20152-7.

Gregersen N, Viljoen D. Costello syndrome with growth hormone deficiency and hypoglycemia: a new report and review of the endocrine associations. Am J Med Genet A. 2004; 129A(2):171-5

Gripp KW, Scott CI, Jr., Nicholson L, McDonaldMcGinn DM, Ozeran JD, Jones MC, et al. Five additional Costello syndrome patients with rhabdomyosarcoma: proposal for a tumor screening protocol. Am J Med Genet. 2002; 108(1):80-7.

Gripp KW. Tumor predisposition in Costello syndrome. Am J Med Genet C Semin Med Genet. 2005;137C(1):72-7.

Gripp KW, Lin AE, Stabley DL, Nicholson L, Scott CI, Jr., Doyle D, et al. HRAS mutation analysis in Costello syndrome: genotype and phenotype correlation. Am J Med Genet A. 2006a;140(1):1-7.

Gripp KW, Stabley DL, Nicholson L, Hoffman JD, Sol-Church K. Somatic mosaicism for an HRAS mutation causes Costello syndrome. Am J Med Genet A. 2006b;140(20):2163-9.

Gripp KW, Lin AE. Costello syndrome: a Ras/mitogen activated protein kinase pathway syndrome (RASopathy) resulting from HRAS germline mutations. Genet Med. 2012;14(3): 285-92.

Gripp KW, Robbins KM, Sheffield BS, Lee AF, Patel MS, Yip S, et al. Paternal uniparental disomy $11 \mathrm{p} 15.5$ in the pancreatic nodule of an infant with Costello syndrome: shared mechanism for hyperinsulinemic hypoglycemia in neonates with Costello and Beckwith-Wiedemann syndrome and somatic loss of heterozygosity in Costello syndrome driving clonal expansion. Am J Med Genet A. 2016;170(3): 559-64.

Gripp KW, Kolbe V, Brandenstein LI, Rosenberger G. Attenuated phenotype of Costello syndrome and early death in a patient with an HRAS mutation (c.179G $>$ T; p.Gly60Val) affecting signalling dynamics. Clin Genet. 2017; 92(3):332-7.
Gripp KW, Morse LA, Axelrad M, Chatfield KC, Chidekel A, Dobyns W, et al. Costello syndrome: clinical phenotype, genotype, and management guidelines. Am J Med Genet A. 2019;179(9):1725-44.

Guzzetti C, Ibba A, Pilia S, Beltrami N, Di Iorgi N, Rollo A, et al. Cut-off limits of the peak GH response to stimulation tests for the diagnosis of GH deficiency in children and adolescents: study in patients with organic GHD. Eur J Endocrinol. 2016;175(1):41-7.

Hennekam RC. Costello syndrome: an overview. Am J Med Genet C Semin Med Genet. 2003; $117 \mathrm{C}(1): 42-8$.

Hussain K, Cosgrove KE, Shepherd RM, Luharia A, Smith VV, Kassem S, et al. Hyperinsulinemic hypoglycemia in Beckwith-Wiedemann syndrome due to defects in the function of pancreatic beta-cell adenosine triphosphatesensitive potassium channels. J Clin Endocrinol Metab. 2005;90(7):4376-82.

Kerr B, Einaudi MA, Clayton P, Gladman G, Eden $\mathrm{T}$, Saunier $\mathrm{P}$, et al. Is growth hormone treatment beneficial or harmful in Costello syndrome? J Med Genet. 2003;40(6):e74.

Kerr B, Delrue MA, Sigaudy S, Perveen R, Marche $\mathrm{M}$, Burgelin I, et al. Genotype-phenotype correlation in Costello syndrome: HRAS mutation analysis in 43 cases. J Med Genet. 2006; 43(5):401-5.

Legault L, Gagnon C, Lapointe N. Growth hormone deficiency in Costello syndrome: a possible explanation for the short stature. J Pediatr. 2001;138(1):151-2.

Lin AE, Grossfeld PD, Hamilton RM, Smoot L, Gripp KW, Proud V, et al. Further delineation of cardiac abnormalities in Costello syndrome. Am J Med Genet. 2002;111(2):115-29.

Lin AE, O'Brien B, Demmer LA, Almeda KK, Blanco CL, Glasow PF, et al. Prenatal features of Costello syndrome: ultrasonographic findings and atrial tachycardia. Prenat Diagn. 2009;29(7):682-90.

Lo IF, Brewer C, Shannon N, Shorto J, Tang B, Black $\mathrm{G}$, et al. Severe neonatal manifestations of Costello syndrome. J Med Genet. 2008; 45(3):167-71. 
Munns CF, Batch JA.. Hyperinsulinism and Beckwith-Wiedemann syndrome. Arch Dis Child Fetal Neonatal Ed. 2001;84, 1:F67-69.

Myers A, Bernstein JA, Brennan ML, Curry C, Esplin ED, Fisher J, et al. Perinatal features of the RASopathies: Noonan syndrome, cardiofaciocutaneous syndrome and Costello syndrome. Am J Med Genet A. 2014;164A(11):2814-21.

Niihori T, Aoki Y, Okamoto N, Kurosawa K, Ohashi H, Mizuno S, et al. HRAS mutants identified in Costello syndrome patients can induce cellular senescence: possible implications for the pathogenesis of Costello syndrome. J Hum Genet. 2011;56(10):707-15.

Okamoto N, Chiyo H, Imai K, Otani K, Futagi Y. A Japanese patient with the Costello syndrome. Hum Genet. 1994;93, 5:605-6.

Quezada E, Gripp KW.. Costello syndrome and related disorders. Curr Opin Pediatr. 2007; 19(6):636-44.

Ranke MB. Growth hormone deficiency: diagnostic principles and practice, in Ranke MB, Mullis PE (eds): Diagnostics of Endocrine Function in Children and Adolescents. Karger, Basel, 2011; p 102.

Rauen KA.. The RASopathies. Annu Rev Genomics Hum Genet. 2013;14:355-69.

Robbins KM, Stabley DL, Holbrook J, Sahraoui R, Sadreameli A, Conard K, et al. Paternal uniparental disomy with segmental loss of heterozygosity of chromosome 11 are hallmark characteristics of syndromic and sporadic embryonal rhabdomyosarcoma. Am J Med Genet A. 2016;170(12):3197-206.
Sheffield BS, Yip S, Ruchelli ED, Dunham CP, Sherwin E, Brooks PA, et al. Fatal congenital hypertrophic cardiomyopathy and a pancreatic nodule morphologically identical to focal lesion of congenital hyperinsulinism in an infant with Costello syndrome: case report and review of the literature. Pediatr Dev Pathol. 2015;18(3):237-44.

Sol-Church K, Stabley DL, Nicholson L, Gonzalez IL, Gripp KW. Paternal bias in parental origin of HRAS mutations in Costello syndrome. Hum Mutat. 2006;27(8):736-41.

Sol-Church K, Gripp KW. The molecular basis of Costello syndrome. In: Zenker $\mathrm{M}$, editor. Noonan Syndrome and Related Disorders- a Matter of Deregulated Ras Signaling. Basel, Switzerland: Karger; 2009.p. 94-103.

Sol-Church K, Stabley DL, Demmer LA, Agbulos A, Lin AE, Smoot L, et al. Male-to-male transmission of Costello syndrome: G12S HRAS germline mutation inherited from a father with somatic mosaicism. Am J Med Genet A. 2009; 149A(3):315-21.

Stein RI, Legault L, Daneman D, Weksberg R, Hamilton J. Growth hormone deficiency in Costello syndrome. Am J Med Genet A. 2004; 129A(2):166-70.

Szalai S, Becker K, Török E. Costello syndrome with decreased glucose tolerance. Eur J Dermatol. 1999;9(7):533-6.
Tamame T, Hori N, Homma H, Yoshida R, Inokuchi M, Kosaki K, et al. Hyperinsulinemic hypoglycemia in a newborn infant with trisomy 13. Am J Med Genet A. 2004;129A(3): 321-2.

Taskiran EZ, Karaosmanoglu B, Koșukcu C, Doğan ÖA, Taylan-Şekeroğlu H, ŞimşekKiper PÖ, et al. Homozygous indel mutation in CDH11 as the probable cause of ElsahyWaters syndrome. Am J Med Genet A. 2017; 173(12):3143-52.

Tidyman WE, Rauen KA. Expansion of the RASopathies. Curr Genet Med Rep. 2016;4(3): 57-64.

van Eeghen AM, van Gelderen I, Hennekam RC. Costello syndrome: report and review. Am J Med Genet. 1999;82(2):187-93.

Wagner IV, Paetzold C, Gausche R, Vogel M, Koerner A, Thiery J, et al. Clinical evidencebased cutoff limits for GH stimulation tests in children with a backup of results with reference to mass spectrometry. Eur J Endocrinol. 2014;171(3):389-97.

White SM, Graham JM, Jr., Kerr B, Gripp K, Weksberg R, Cytrynbaum C, et al. The adult phenotype in Costello syndrome. Am J Med Genet A. 2005;136(2):128-35.

Yetkin I, Ayvaz G, Arslan M, Yilmaz M, Cakir N. A case of Costello syndrome with endocrine features. Ann Genet. 1998;41(3):157-60. 